\title{
Nutrient Supply and Neutralizing Value of Alfalfa Stem Gasification Ash
}

\author{
Morteza Mozaffari, Michael P. Russelle, Carl J. Rosen,* and Edward A. Nater
}

\begin{abstract}
Energy generation from biomass is an environmentally sound alternative to other energy producing technologies. Pilot studies have indicated that alfalfa (Medicago sativa $L_{\text {. }}$ ) is a suitable feedstock for energy generation via the gasification process. The resulting ash is a potential liming agent and a source of plant nutrients. A growth chamber study was conducted with three soils to evaluate the potential use of this ash as a soil amendment. Corn (Zea mays L.) received 13 treatments: control, $K$ and/or $P$ fertilizer, seven ash rates $(0.6$ to $14.6 \mathrm{~g}$ ash $\mathrm{kg}^{-1}$ soil), and one ash rate with $\mathrm{K}$ or $\mathrm{P}$ fertilizer. Soil $\mathrm{pH}$ increased with ash application on all soils. Ash application increased ammonium acetate-exchangeable $\mathrm{K}$, $\mathrm{Ca}$, and $\mathrm{Mg}$, and Olsen $P$ in soil and decreased DTPA-extractable soil $\mathrm{Fe}, \mathrm{Mn}, \mathrm{Ni}$, and $\mathrm{Pb}$. Averaged across the three soils, slopes of the cations recovered in plant and soil vs. cations applied in the ash were $0.48,0.21$, and 0.22 of total ash $K$, $\mathrm{Ca}$, and $\mathrm{Mg}$, respectively $\left(r^{2}>0.97\right)$. Ash significantly increased plant $\mathrm{K}$ and $\mathrm{Mo}$, and decreased $\mathrm{Mg}, \mathrm{Mn}$, and $\mathrm{Zn}$ concentration. Tissue $\mathrm{P}$ concentrations were not affected by ash, but increased with $P$ fertilizer. Phosphorus fertilizer increased plant dry mass (DM), but K fertilizer did not, thus $\mathrm{K}$ did not limit yield. Alfalfa stem gasification ash is a potential liming agent, a source of $K$, and would not lead to excessive accumulation of trace elements in soil or plants when applied at rates based on lime or $\mathrm{K}$ need.
\end{abstract}

A HAS BEEN RECOGNIZED as an excellent soil amendment since well before Jared Eliot wrote in 1748, "Ashes is allowed on all hands to be some of the best dressing or manure for land; it enricheth much and lasts long; but the misery is we can get but little" (Eliot, 1934; Carman, 1934). Eliot was referring mainly to wood and coal ash, which are available today in large amounts from electricity generation. Effects of coal and wood ash on soil chemical properties, and on plant yield and elemental composition have been investigated, and recent reviews include Hammermeister et al. (1998) on coal ash and Mitchell and Black (1997) and Vance (1996) on wood ash.

The major effects of land application of ash are changes in soil $\mathrm{pH}$ and nutrient availability. Ash has been used historically and primarily as a liming agent or K source. The liming potential or calcium carbonate equivalent (CCE) of ash is dependent both on the type of ash and soil chemical properties (Clapham and Zibilske, 1992). Wood ash is generally rich in oxides, hydroxides, and carbonates of $\mathrm{Ca}, \mathrm{K}$, and $\mathrm{Mg}$, and contains small quantities of micronutrients (Erich and Ohno, 1992; Mitchell and Black, 1997).

M. Mozaffari, C.J. Rosen, and E.A. Nater, Dep. of Soil, Water, and Climate, 439 Borlaug Hall, 1991 Upper Buford Circle, Univ. of Minnesota. St. Paul, MN 55108; M.P. Russelle, USDA-ARS U.S. Dairy Forage Research Center (Minnesota Cluster) and Dep. of Soil, Water, and Climate, 439 Borlaug Hall, Univ. of Minnesota. St. Paul, MN 55108; Joint contribution of the Minnesota Agric. Exp. Stn. and the USDA-ARS. Received 8 Aug. 2000. *Corresponding author (crosen@ soils.umn.edu).

Published in Soil Sci. Soc. Am. J. 66:171-178 (2002).
Ash application influences availabilities of plant micronutrients either directly through addition of its micronutrients constituents or indirectly through the modification of soil $\mathrm{pH}$. Increased availability of $\mathrm{B}$ and $\mathrm{Mo}$ has been reported in soils amended with ash from power plants (Codling and Wright, 1998; Hammermeister et al., 1998). Clapham and Zibilske (1992) reported that wood ash application increased acid-extractable $(\mathrm{pH} \mathrm{3,1M}$ ammonium acetate $\left[\mathrm{NH}_{4} \mathrm{OAc}\right]$ ) soil $\mathrm{Fe}, \mathrm{Zn}, \mathrm{Cu}$, and $\mathrm{Mn}$, but in another study, wood ash decreased extractable Fe and Al (Naylor and Schmidt, 1986).

Modification of soil chemical properties by ash application has resulted in altered elemental composition of plants. Wood ash increased the K concentration in corn and winter wheat (Triticum aestivum L.) in greenhouse studies (Erich, 1991; Etiegni et al., 1991a) and alfalfa in field studies (Meyers and Kopecky, 1998). Wood ash at rates below $20 \mathrm{~g} \mathrm{~kg}^{-1}$ increased $\mathrm{P}$ concentration in wheat (Etiegni et al., 1991a). Other studies have shown that $\mathrm{P}$ availability can increase or decrease in ash-amended soils (Erich, 1991; Voundinkana et al., 1998; Moliner and Street, 1982; Elseewi et al., 1980). Application of either coal fly ash or wood ash decreased tissue $\mathrm{Zn}, \mathrm{Fe}$, and Mn, and increased B and Mo (Elseewi et al., 1980; Francis et al., 1985; Naylor and Schmidt, 1989). Application of wood-fired boiler ash decreased the concentrations of $\mathrm{Mn}$ and $\mathrm{Cu}$ in bean (Phaseolus vulgaris L.) plants (Krejsl and Scanlon, 1996). These effects on plant micronutrient concentration may have implications for human or animal health.

Plant DM production has increased, decreased, or remained unchanged after coal or wood ash application, depending on factors such as type and rate of ash application, plant species, and soil properties. Oat (Avena sativa L.) grown in soil amended with $30 \mathrm{Mg} \mathrm{ha}^{-1}$ of wood-fired boiler ash produced significantly higher DM than plants grown in nonamended soil, but DM declined at $50 \mathrm{Mg} \mathrm{ha}^{-1}$ ash (Krejsl and Scanlon, 1996). Wood ash application had no effect on production of spinach (Spinacia oleracea L.) in a greenhouse study (Clapham and Zibliskie, 1992) nor on wheat yield in a field study (Huang et al., 1992).

In recent years, utilization of herbaceous species as biomass fuel for electricity generation has been viewed as an environmentally viable option. Preliminary studies have indicated that alfalfa stems are suitable feedstock for energy generation via the gasification process (Wilbur et al., 1998). If the ash from alfalfa gasification can be utilized as a soil amendment, then economic viability and public acceptance of this alternative energy source may increase. Chemical characterization has indicated that alfalfa ash is a potential liming agent, its macronutrient content is equivalent to a 1-1-10 fertilizer, and it

Abbreviations: CCE, calcium carbonate equivalent; DM, dry matter ICP-AES, inductively coupled plasma atomic emission spectroscopy. 
Table 1. Selected physical and chemical properties of the Hubbard, Waukegan, and Wykeham soils used in the growth chamber experiment.

\begin{tabular}{|c|c|c|c|}
\hline Property & Hubbard & Waukegan & Wykeham \\
\hline $\mathbf{p H} \dagger$ & 4.9 & 6.3 & 7.0 \\
\hline $\mathbf{E C}+, \mathrm{dS} \mathbf{m}^{-1}$ & 1.4 & 0.3 & 1.4 \\
\hline Organic matter $\$, \mathbf{g ~ k g}^{-1}$ & 0.1 & 0.5 & 0.3 \\
\hline $1 M \mathrm{NH}_{4} \mathrm{OAc} \mathrm{K}, \mathrm{mg} \mathrm{kg}^{-1}$ & 66 & 69 & 78 \\
\hline Bray-P1 P, mg kg-1 & 99 & 24 & 9 \\
\hline \multicolumn{4}{|l|}{ DTPA-extractable metals } \\
\hline Fe, $\mathrm{mg} \mathrm{kg}^{-1}$ & 27 & 68 & 46 \\
\hline $\mathbf{M n}, \mathbf{m g ~ k g} \mathbf{~ k g}^{-1}$ & 13 & 30 & 12 \\
\hline $\mathrm{Zn}, \mathrm{mg} \mathrm{kg}^{-1}$ & 1.1 & 1.8 & 0.7 \\
\hline $\mathrm{Cu}, \mathrm{mg} \mathrm{kg}^{-1}$ & 0.4 & 0.7 & 0.6 \\
\hline Pb, mg kg $\mathbf{~}^{-1}$ & 0.4 & 1.2 & 0.6 \\
\hline $\mathrm{Ni}, \mathrm{mg} \mathrm{kg}^{-1}$ & 0.4 & 1.6 & 0.8 \\
\hline Sand, $\mathbf{g ~ k g}^{-1}$ & 880 & 200 & 640 \\
\hline Silt, $\mathrm{g} \mathrm{kg}^{-1}$ & 80 & 540 & 230 \\
\hline Clay, $\mathrm{g} \mathrm{kg}^{-1}$ & 40 & 260 & 130 \\
\hline Moisture at $-0.03 \mathrm{MPa}, \mathrm{g} \mathrm{kg}^{-1}$ & 40 & 280 & 170 \\
\hline
\end{tabular}

$\dagger 1: 1 \mathrm{w} / \mathrm{w} \mathrm{H}_{2} \mathrm{O}$.

† Saturated paste extract.

$\S$ Walkey Black method. (Combs and Nathan, 1998; Combs and Whitney, 1998.)

also contains other soluble elements (Mozaffari et al., 2000a). A greenhouse experiment with corn indicated that alfalfa ash might be a source of $\mathrm{K}$ and a good liming material for acid soils (Mozaffari et al., 2000b). The objective of this research was to further evaluate these potential benefits and the potential deleterious effects of alfalfa stem gasification ash on soil chemical properties and on early corn growth and shoot composition.

\section{MATERIALS AND METHODS}

\section{Soils and Ash}

The experiment was conducted with three representative agricultural soils of Minnesota: a Hubbard sand (sandy, mixed, frigid Entic Hapludolls), a Waukegan silt loam (fine silty over sandy or sandyskeletal, mixed, mesic Typic Hapludolls), and a Wykeham sandy loam (fine-loamy, mixed, superactive, frigid Aquic Hapludalfs). A bulk sample of $20 \mathrm{~cm}$ of each soil was collected from the surface and was air dried. Selected chemical and physical characteristics of the three soils are listed in Table 1. All sites were chosen based on our expectation that a crop K response would be likely. The Hubbard is an acid, very high $\mathrm{P}$, and medium $\mathrm{K}$ soil; Waukegan is a slightly acid, high $\mathrm{P}$, and medium $\mathrm{K}$ soil; and Wykeham is a neutral $\mathrm{pH}$, low $\mathrm{P}$, medium $\mathrm{K}$ soil.

The alfalfa stem ash used in this study was the byproduct of a gasification test that utilized alfalfa grown in Minnesota as feedstock. The fly ash had a $\mathrm{pH}$ of $11.8\left(1: 1 \mathrm{w} / \mathrm{w} \mathrm{H}_{2} \mathrm{O}\right)$, CCE of $400 \mathrm{~g} \mathrm{~kg}^{-1}$ (Johnson, 1990a), $9 \mathrm{~g} \mathrm{P} \mathrm{kg}^{-1}$, and $100 \mathrm{~g} \mathrm{~K}$ $\mathrm{kg}^{-1}$ in the ammonium citrate extract (Johnson, 1990b), and $13 \mathrm{~g} \mathrm{~kg}^{-1}$ total $\mathrm{N}$. The saturated paste extract had an electrical conductivity (EC) of $130 \mathrm{dS} \mathrm{m}^{-1}$ and contained $78 \mathrm{~g} \mathrm{~K} \mathrm{~L}^{-1}$, $147 \mathrm{mg} \mathrm{P} \mathrm{L}^{-1}, 4.5 \mathrm{mg} \mathrm{B} \mathrm{L}^{-1}$, and $20 \mathrm{~g} \mathrm{Cl} \mathrm{L}^{-1}$. Comprehensive chemical characterization of the ash was reported by Mozaffari et al. (2000a).

\section{Experimental Treatments}

The 13 treatments included a control, seven fly ash rates ranging from 0.61 to $14.6 \mathrm{~g}$ ash $\mathrm{kg}^{-1}$ soil (equivalent to 0.9 to 21.6 $\mathrm{Mg} \mathrm{ha}^{-1}$ ), $\mathrm{K}$ fertilizer, $\mathrm{P}$ fertilizer, $\mathrm{K}+\mathrm{P}$ fertilizer, ash + $\mathrm{K}$ fertilizer, and ash $+\mathrm{P}$ fertilizer. Reagent grade $\mathrm{KCl}$ and secondary dibasic $\mathrm{CaHPO}_{4}$ were used as sources of $\mathrm{K}$ and $\mathrm{P}$ fertilizer, respectively. Detailed information on fertilizer and
Table 2. Fertilizer and ash treatments used in the growth chamber study and the amount of $K$ and/or $P$ supplied by each treatment.

\begin{tabular}{|c|c|c|c|c|}
\hline \multirow[b]{2}{*}{ Treatment } & \multicolumn{2}{|c|}{$\mathbf{K}$} & \multicolumn{2}{|c|}{$\mathbf{P}$} \\
\hline & Ash & Fert. & Ash & Fert. \\
\hline & & - & & \\
\hline $\begin{array}{l}\text { Control } \\
\text { K fertilizer }\end{array}$ & 0 & $\begin{array}{r}0 \\
120\end{array}$ & 0 & 0 \\
\hline P fertilizer & & & & 39 \\
\hline $\mathbf{K}+\mathbf{P}$ fertilizer & & 120 & & 39 \\
\hline Ash $+\mathbf{K}$ fertilizer & 488 & 120 & 39 & \\
\hline Ash + P fertilizer & 488 & & 39 & 39 \\
\hline Ash rates, $\mathbf{g ~ k g}^{-1}$ & & & & \\
\hline 0.61 & 61 & & 4.9 & \\
\hline 1.22 & 122 & & 9.6 & \\
\hline 2.44 & 244 & & 20 & \\
\hline 4.88 & 488 & & 39 & \\
\hline 7.32 & 732 & & 58 & \\
\hline 9.76 & 976 & & 79 & \\
\hline 14.6 & 1460 & & 117 & \\
\hline
\end{tabular}

$\dagger \mathbf{K}$ and $\mathbf{P}$ fertilizer are expressed in grams of each nutrient element per kilogram of soil.

ash rates and the amount of $\mathrm{K}$ and $\mathrm{P}$ supplied by each treatment is provided in Table 2 . The fertilizer treatments were included to assess whether corn responded to $\mathrm{K}$ or $\mathrm{P}$ in these soils. Soil and amendments for all four replications of each treatment were mixed thoroughly in one batch to reduce variability among replications. Ammonium nitrate was added to all treatments at the rate of $0.18 \mathrm{~g} \mathrm{~kg}^{-1}$ at planting and topdressed at the same rate 10 and $20 \mathrm{~d}$ after seedling emergence (total of $0.54 \mathrm{~g} \mathrm{~N} \mathrm{~kg}^{-1} \mathrm{NH}_{4} \mathrm{NO}_{3}$ ). After mixing, three replications of each treatment were prepared by placing $1.4 \mathrm{~kg}$ of amended soil in a $15-\mathrm{cm}$ diam. 2.1-L plastic pot placed on a 20-cm diam. saucer. Six corn seeds (Pioneer Hi-Bred 3730 ${ }^{1}$ ) were planted in each pot. Treatments were randomly arranged by soil within three growth chambers, with each replication assigned to a separate growth chamber. A 14-h photoperiod at about $400 \mu \mathrm{mol} \mathrm{m} \mathrm{s}^{-2} \mathrm{~s}^{-1}$ of photosynthetic photon flux was provided by fluorescent lights and temperature was maintained at $30^{\circ} \mathrm{C}$ during the light and $15^{\circ} \mathrm{C}$ during the dark. Seedlings were thinned to one per pot $1 \mathrm{wk}$ after emergence. Daily watering maintained soil moisture at approximately field capacity. Leaching loss of soluble elements was minimized by returning any water leached into the saucers to the soil. Corn shoots were harvested $39 \mathrm{~d}$ after plant emergence. Plants were dried in a forced air oven at $65^{\circ} \mathrm{C}$ and their dry weights were measured. Dried plants were ground and a subsample was used for chemical analysis. After plant harvest, composite soil samples of five $2.5-\mathrm{cm}$ diam. cores were collected from each pot.

\section{Chemical Analysis of Soil and Plant Samples}

Soil samples were extracted for exchangeable $\mathrm{K}, \mathrm{Na}, \mathrm{Ca}$, and, $\mathrm{Mg}$ by $1 M \mathrm{NH}_{4} \mathrm{OAc}$ (Sumner and Miller, 1996) and for $\mathrm{Cu}, \mathrm{Zn}, \mathrm{Fe}, \mathrm{Mn}, \mathrm{Cr}, \mathrm{Cd}, \mathrm{Ni}$, and $\mathrm{Pb}$ by $0.005 \mathrm{M}$ DTPA (adjusted to $\mathrm{pH}$ 7.3) extraction (Reed and Martens, 1996). Concentrations of the elements in all extracts were determined by inductively coupled plasma atomic emission spectroscopy (ICP-AES) (Dahlquist and Knoll, 1978). Soil P was extracted by Olsen method (Kuo, 1996) and determined by ICP-AES. Soil $\mathrm{pH}$ and EC in 1:1 soil/water $(\mathrm{w} / \mathrm{w})$ suspension was measured as described by Watson and Brown (1998) and Whitney (1998), respectively.

\footnotetext{
${ }^{1}$ Mention of a trademark or a proprietary product does not constitute a guarantee or warranty of the product by the Univ. of Minnesota or USDA and does not imply its approval to the exclusion of other products that may also be suitable.
} 
Plant samples were digested in $\mathrm{HNO}_{3}$ in a microwave by the wet ashing procedure (Miller, 1998) and concentrations of $\mathrm{P}, \mathrm{K}, \mathrm{Ca}, \mathrm{Mg}, \mathrm{Na}, \mathrm{Al}, \mathrm{Fe}, \mathrm{Mn}, \mathrm{Zn}, \mathrm{Cu}, \mathrm{B}, \mathrm{Pb}, \mathrm{Ni}, \mathrm{Cr}, \mathrm{Cd}$, and Mo were measured by ICP-AES.

\section{Statistical Treatment of Data}

The SAS software package was used for statistical analysis of the data (SAS, 1996). Analysis of variance (ANOVA) was used to discern significant treatment effects on soil chemical properties, and on corn yield or elemental concentration. Experimental design was a split plot (soil as the main plot) randomized complete block. Only significant effects $(P<0.05)$ are presented. When the ANOVA indicated a significant soil by treatment effect for soil or plant responses, the response variables for each soil were analyzed and are presented separately. Regression was used to generalize soil or plant response to ash application (Barrow and Mendoza, 1990; SAS, 1996), when warranted by linear, quadratic, or residual terms of orthogonal contrasts for ash rate. The inorganic fertilizer treatments and fertilizer plus ash treatments were not included in regression equations.

\section{RESULTS AND DISCUSSION}

\section{Soil Chemical Properties}

\section{Soil pH and Electrical Conductivity}

Unlike our earlier results, which showed no $\mathrm{pH}$ response to ash in a high $\mathrm{pH}$ clay loam soil and a linear response in the Hubbard sand (Mozaffari et al., 2000b), all three soils in this experiment showed curvilinear $\mathrm{pH}$ responses to ash addition $\mathrm{pH}$ (Fig. 1, Table 3). The earlier experiment included ash rates only to $6.4 \mathrm{~g} \mathrm{~kg}^{-1}$ soil, and data from Hubbard soil in the current experiment confirmed this linear relationship of $\mathrm{pH}$ to ash application up to $7.3 \mathrm{~g} \mathrm{~kg}^{-1}\left(r^{2}=0.98\right)$. In the two acid soils, 2.2 or $2.8 \mathrm{~g} \mathrm{~kg}^{-1}$ alfalfa stem ash was required to increase $\mathrm{pH}$ to 6.5 (Fig. 1), a level adequate for most major crops. Other greenhouse studies have also demonstrated an increase in soil $\mathrm{pH}$ with wood ash or combined boiler ash (Meyers and Kopecky, 1998; Krejsl and Scanlon, 1996; Etiegni et al., 1991a).

Soil EC increased with ash application in all three soils (Fig. 1, Table 3). Ranking of soil EC did not change with ash rate, and the highest observed value was $1.82 \mathrm{dS}$ $\mathrm{m}^{-1}$ in Wykeham soil. In Hubbard and Waukegan soils, addition of $1 \mathrm{~g} \mathrm{~kg}^{-1}$ of ash increased the EC by about $0.03 \mathrm{dS} \mathrm{m}^{-1}\left(y=0.14+0.025 x\right.$ for Hubbard, $\left.r^{2}=0.94\right)$. Rate of increase was twice as fast in Wykeham soil, at $0.056 \mathrm{dS} \mathrm{m}^{-1}$ for each $\mathrm{g} \mathrm{kg}^{-1}$ ash addition (Fig. 1). The increase in salinity because of this ash is similar to responses to wood and coal fly ash (Clapham and Zibilske, 1992; Sale et al., 1996; Matsi and Keramidas, 1999).

\section{Exchangeable Cations}

Ash application increased exchangeable $\mathrm{K}, \mathrm{Ca}$, and $\mathrm{Mg}$ in all soils, and increased $\mathrm{Na}$ in Waukegan and Wykeham soils (Table 3). A linear relationship existed between ash application rates and the levels of exchangeable $\mathrm{Ca}, \mathrm{Mg}$, and $\mathrm{Na}\left(r^{2}>0.80\right.$, except no effect on $\mathrm{Na}$ in Hubbard soil), whereas $\mathrm{K}$ increased more quickly, the higher the ash rate (Fig. 1) (data not shown
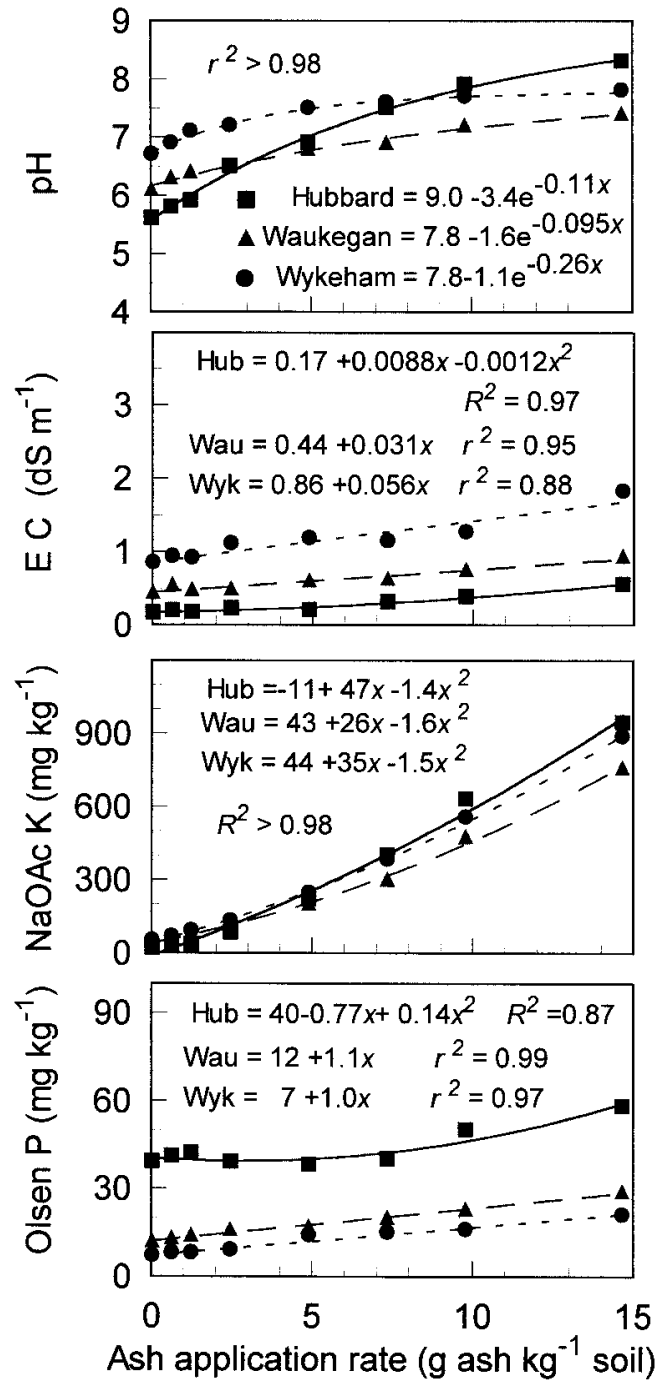

Fig. 1. Response of chemical characteristics of Hubbard, Waukegan, and Wykeham soils to alfalfa stem gasification fly ash.

for $\mathrm{Ca}, \mathrm{Mg}$, and $\mathrm{Na}$ ). In all three soils, the ranking of increases in exchangeable cations followed the pattern $\mathrm{K}>\mathrm{Ca}>\mathrm{Mg}$, consistent with concentrations of these elements in the ash (Mozaffari et al., 2000a).

The amount of $\mathrm{K}, \mathrm{Ca}$, and $\mathrm{Mg}$ recovered in plant and soil (the sum of each exchangeable cation in postharvest soils plus the amount of each cation removed by the plants) was correlated with the total amount of each cation added by the ash. Averaged across the three soils, slopes of the cations recovered in plant and soil vs. total amount of each cation applied in the ash were $0.48,0.21$, and $0.22\left(r^{2}>0.97\right)$ for $\mathrm{K}, \mathrm{Ca}$, and $\mathrm{Mg}$, respectively. About $60 \%$ of the ammonium citrate extractable K supplied by ash was accounted for in soil and shoot tissue, averaged across soils. Based on plant $\mathrm{K}$ uptake alone, and using the first four ash rates (linear fit $r^{2}>0.99$ ), apparent ash $\mathrm{K}$ absorption by the 39-d-old corn was $62 \%$ in Hubbard soil and $40 \%$ in Waukegan soil. Poor plant growth on the Wykeham soil resulted in a recovery of only $7 \%$ of applied K (linear fit $r^{2}=0.67$ ). The increase in exchangeable cations because of ash application is consistent with results of other laboratory, green- 
Table 3. Probabilities of a greater $F$ statistic in single degree-of-freedom orthogonal contrasts in the ANOVA for the effect of ash on soil pH, EC, Olsen P, ammonium acetate-exchangeable cations, and DTPA-extractable metals, and on plant response.

\begin{tabular}{|c|c|c|c|c|c|c|c|c|c|c|c|c|c|c|c|c|}
\hline \multirow[b]{2}{*}{ Soil } & \multirow[b]{2}{*}{ Effect } & \multicolumn{13}{|c|}{ Soil parameters } & \multicolumn{2}{|c|}{ Corn parameters } \\
\hline & & pH & EC & Olsen-P & $\mathbf{K}$ & $\mathrm{Ca}$ & Mg & $\mathbf{N a}$ & $\mathbf{F e}$ & Mn & Mo & $\mathbf{N i}$ & $\mathbf{P b}$ & DM & K uptake & P uptake \\
\hline \multirow[t]{4}{*}{ Hubbard } & Ash rate & $* *$ & $* *$ & $* *$ & $* *$ & $* *$ & $* *$ & $\mathbf{N S} \dagger$ & $* *$ & $* *$ & $* *$ & $* *$ & $* *$ & $* *$ & $* *$ & $*$ \\
\hline & Linear & $* *$ & $* *$ & $* *$ & $* *$ & $* *$ & $* *$ & NS & $* *$ & $* *$ & $* *$ & $* *$ & $* *$ & $* *$ & $* *$ & $* *$ \\
\hline & Quadratic & $* *$ & $* *$ & $* *$ & $* *$ & $* *$ & $* *$ & NS & $* *$ & $* *$ & NS & $* *$ & $* *$ & $* *$ & $* *$ & $*$ \\
\hline & Residual & NS & NS & NS & NS & NS & NS & NS & $*$ & NS & NS & $* *$ & NS & NS & $* *$ & NS \\
\hline \multirow[t]{4}{*}{ Waukegan } & Ash rate & $* *$ & $* *$ & $* *$ & $* *$ & $* *$ & $* *$ & $* *$ & $* *$ & $* *$ & $* *$ & $* *$ & $* *$ & NS & $* *$ & NS \\
\hline & Linear & $* *$ & $* *$ & $* *$ & $* *$ & $* *$ & $* *$ & $* *$ & $* *$ & $* *$ & $* *$ & $* *$ & $* *$ & NS & $* *$ & NS \\
\hline & Quadratic & $* *$ & NS & NS & $* *$ & NS & NS & NS & $* *$ & $*$ & NS & $* *$ & NS & NS & $* *$ & $* *$ \\
\hline & Residual & NS & NS & NS & NS & NS & NS & NS & NS & NS & NS & NS & NS & NS & NS & NS \\
\hline \multirow{4}{*}{ Wykeham } & Ash rate & $* *$ & $* *$ & $* *$ & $* *$ & $* *$ & $* *$ & $* *$ & $* *$ & $* *$ & $* *$ & $* *$ & $* *$ & $*$ & $* *$ & $*$ \\
\hline & Linear & $* *$ & $* *$ & $* *$ & $* *$ & $* *$ & $* *$ & $* *$ & $* *$ & $* *$ & $* *$ & $* *$ & $* *$ & $* *$ & $* *$ & $* *$ \\
\hline & Quadratic & $* *$ & NS & NS & $*$ & NS & NS & NS & $* *$ & $* *$ & NS & $* *$ & $*$ & NS & NS & NS \\
\hline & Residual & NS & $* *$ & NS & NS & NS & NS & NS & NS & NS & NS & NS & NS & NS & NS & NS \\
\hline
\end{tabular}

* Significant at 0.05 probability level.

** Significant at 0.01 probability level.

$\dagger$ Not significant.

house, and field studies conducted with other types of biomass-derived ashes (Muse and Mitchell, 1995; Naylor and Schmidt, 1989; Ohno and Erich, 1990). Our results indicate that, similar to other ashes, alfalfa stem gasification ash is a source of basic cations, particularly $\mathrm{K}$.

\section{Available Phosphorus}

Ash application increased Olsen-extractable $\mathrm{P}$ in all three soils (Fig. 1, Table 3). Olsen P in Waukegan and Wykeham soil increased to 29 and $21 \mathrm{mg} \mathrm{kg}^{-1}$, respectively. This increase was because of $\mathrm{P}$ addition in the ash, perhaps to the liming effect of ash on $\mathrm{P}$ availability in Waukegan soil, and possibly to less neutralization of the Olsen bicarbonate extractant in acid soils as soil $\mathrm{pH}$ rose. Corn grain yield grown on soils with Olsen $\mathrm{P}$ values greater than $16 \mathrm{mg} \mathrm{kg}^{-1}$ is not expected to respond to additional P (Rehm et al., 1995), but early corn growth in the field is often greater with higher soil test P.

The relationship between ash application rate and extractable $\mathrm{P}$ was best described by linear regression, except in Hubbard soil, which showed no response until more than $7.5 \mathrm{~g}_{\text {ash }} \mathrm{kg}^{-1}$ soil was applied (Fig. 1). In Wykeham and Waukegan soils, addition of $1 \mathrm{~g} \mathrm{~kg}^{-1}$ of ash ( $9 \mathrm{mg}$ citrate-soluble $\mathrm{P} \mathrm{kg}^{-1}$ soil) increased extractable $\mathrm{P}$ by about $1 \mathrm{mg} \mathrm{kg}^{-1}$. The rate of increase in Olsen P on Hubbard soil was twice as fast, $2.2 \mathrm{mg} \mathrm{kg}^{-1}$ (based on the highest four ash rates to avoid the plateau). Biomass ash often increases soil extractable P.

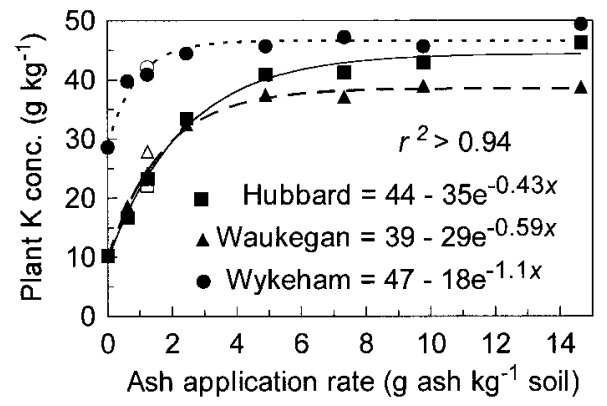

Fig. 2. Effect of alfalfa stem gasification fly ash (closed symbols) and fertilizer $\mathrm{K}$ (open symbols) on $\mathrm{K}$ concentration in corn plants grown in Hubbard, Waukegan, and Wykeham soils for $39 \mathrm{~d}$ under growth chamber conditions.
For example, wood ash at the rate of $20 \mathrm{~g} \mathrm{~kg}^{-1}$ increased the Bray-2 extractable P to $13.5 \mathrm{mg} \mathrm{kg}^{-1}$ from 7.9 in the nonamended control (Voundinkana et al., 1998). These ratios of applied $\mathrm{P}$ to soil test increase are well within the range of results obtained with fertilizer $\mathrm{P}$ in the field (Randall et al., 1997), which implies that alfalfa ash may provide $\mathrm{P}$ to crops.

\section{Available Metals and Nutrients}

DTPA-extractable $\mathrm{Zn}, \mathrm{Cd}, \mathrm{Cr}$, and $\mathrm{Cu}$ were below $2.5,0.08,0.07$, and $1.1 \mathrm{mg} \mathrm{kg}^{-1}$, respectively, and in our experiment were not affected by ash application.

DTPA-extractable $\mathrm{Fe}, \mathrm{Mn}, \mathrm{Ni}$, and $\mathrm{Pb}$ were reduced by ash application (data not shown), with the exception that $\mathrm{Mn}$ increased from 12 to $23 \mathrm{mg} \mathrm{kg} \mathrm{g}^{-1}$ in Hubbard soil when ash rate increased from 9.8 to $14.6 \mathrm{~g} \mathrm{~kg}^{-1}$ ash. Extractable metal concentrations were low in these soils initially and reduced extractability was probably because of the liming effect of the ash. This liming effect on DTPA-extractable metals has been reported for other alkaline biomass ashes (Voundinkana et al., 1998; Krejsl and Scanlon, 1996).

The data suggest that metal toxicity is unlikely in soils amended with alfalfa biomass ash rates based on realistic crop yield goals and soil test value. However, reduced availability of micronutrients associated with very high rates of alfalfa ash may limit potential crop growth. The data also suggest that alfalfa ash may have potential for remediation of acid or neutral soils contaminated with high levels of metals.

\section{Elemental Composition of Young Corn}

There was a significant soil by treatment interaction for $\mathrm{K}, \mathrm{P}, \mathrm{Mn}$, and Mo, but not for $\mathrm{Zn}$ and $\mathrm{Mg}$. Where this interaction occurred, responses to ash are discussed for each soil; otherwise, responses were averaged over soils.

\section{Potassium Concentration and Uptake}

Concentration of $\mathrm{K}$ in plants grown in the nonamended Hubbard, Waukegan, and Wykeham soils was 9, 10, and $29 \mathrm{~g} \mathrm{~kg}^{-1}$, respectively, and both $\mathrm{K}$ fertilizer and ash increased $\mathrm{K}$ concentration (Fig. 2) (data shown for ash 

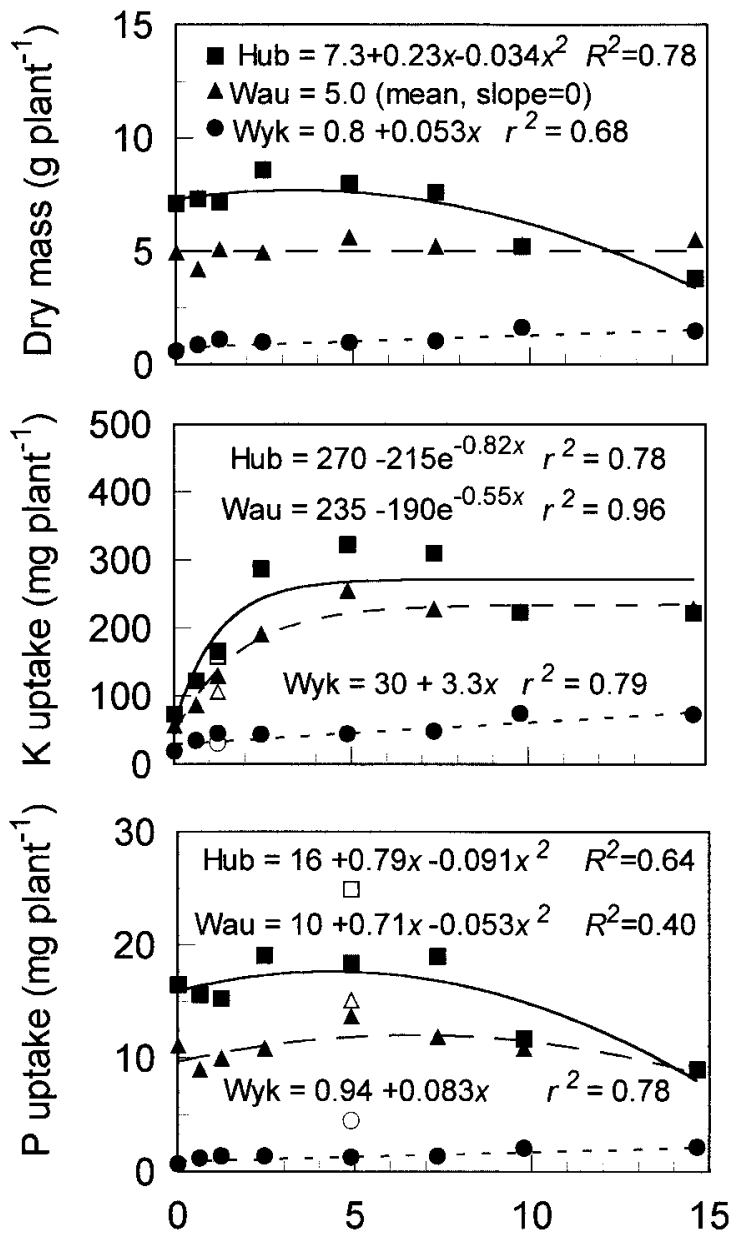

Ash application rate ( $\mathrm{g}$ ash $\mathrm{kg}^{-1}$ soil)

Fig. 3. Effect of alfalfa stem gasification fly ash (closed symbols) and fertilizer $P$ or $K$ (open symbols) on corn shoot dry mass and $K$ and $P$ accumulation after $39 \mathrm{~d}$ under growth chamber conditions.

treatments only). The effect of ash on plant $\mathrm{K}$ was evident at the lowest rate of ash $\left(0.61 \mathrm{~g} \mathrm{~kg}^{-1}\right)$ and approached a plateau at an ash rate between 2 and $6 \mathrm{~g} \mathrm{~kg}^{-1}$, depending on the soil. Initial response on Hubbard and Waukegan soils was comparable, despite lower DM accumulation by plants grown in Waukegan (discussed below), perhaps reflecting the similar original soil $\mathrm{K}$ levels.

Ash application increased $\mathrm{K}$ uptake by corn in all soils, reaffirming that ash supplied $\mathrm{K}$ to the crop (Fig. 3). At the highest ash application rate, $\mathrm{K}$ uptake was at least 2.6 times greater than in the nonamended soil. Moreover, plant $\mathrm{K}$ uptake was $13 \%$ higher with ash than fertilizer $(P<0.01)$ at comparable rates of added $\mathrm{K}$ (120 mg K kg $\mathrm{mg}^{-1}$ soil, $1.2 \mathrm{~g}$ ash kg ${ }^{-1}$ soil).

\section{Phosphorus Concentration and Uptake}

When all ash and fertilizer treatments were included, ANOVA indicated a significant treatment effect on plant $\mathrm{P}$. Concentration of $\mathrm{P}$ in plants grown in the fertilizer-amended soil was higher than in the control $(P<$ $0.01)$. Phosphorus concentration of plants grown in the P-fertilizer treatment in Hubbard, Waukegan, and Wykeham soils was $2.9,2.0$, and $1.8 \mathrm{~g} \mathrm{~kg}^{-1}$, respectively, com-
Table 4. Probabilities of a greater $F$ statistic in single degree-offreedom orthogonal contrasts in the analysis of variance for the effect of ash on elemental concentration of corn plants.

\begin{tabular}{lccccc}
\hline & & \multicolumn{4}{c}{ Source of variation } \\
\cline { 3 - 6 } Soil & Nutrient & Ash & Linear & Quadratic & Residual \\
\hline Hubbard & Mo & $* *$ & $* *$ & NS $\dagger$ & NS \\
Waukegan & Mo & $* *$ & $* *$ & NS & NS \\
Wykeham & Mo & $* *$ & $* *$ & NS & NS \\
All soils & Mg & $* *$ & $* *$ & $* *$ & $* *$ \\
All soils & Zn & $* *$ & $* *$ & $* *$ & NS \\
All soils & Mn & $*$ & NS & NS & NS \\
\hline
\end{tabular}

* Significant at 0.05 probability level.

$* *$ Significant at 0.01 probability level.

$\dagger$ Not significant.

pared with $2.3,1.7$, and $1.2 \mathrm{~g} \mathrm{~kg}^{-1}$ in the respective nonamended soils. In all soils, citrate-soluble $\mathrm{P}$ from fertilizer was more available than citrate-soluble $\mathrm{P}$ from ash, regardless of ash rate. Corn $\mathrm{P}$ concentration did not respond to ash application. We cannot explain the lack of plant $\mathrm{P}$ concentration response in Wykeham soil, where both plant and soil P levels appeared to be deficient, but the ash effect observed here is consistent with the work of Clapham and Zibilske (1992), who reported that $\mathrm{P}$ concentration in spinach was not affected by wood ash application. However, other researchers have reported that $\mathrm{P}$ from wood ash was available for plant uptake (Etiegni et al., 1991a; Erich, 1991). In our work, there was a very small but significant $(P<$ 0.1 ) increase in P uptake in Wykeham soil only (Fig. 3), despite constant tissue $\mathrm{P}$ concentrations.

\section{Other Elements in Corn}

Ash application reduced plant $\mathrm{Mg}, \mathrm{Mn}$, and $\mathrm{Zn}$ concentrations $(P<0.01)$. Corn shoot $\mathrm{Mg}$ concentration declined by $170 \mathrm{mg} \mathrm{kg}^{-1}$ for each $1000 \mathrm{mg} \mathrm{kg}^{-1}$ increase in shoot $\mathrm{K}$ concentration on the two finer-textured soils, and by $60 \mathrm{mg} \mathrm{kg}^{-1}$ in the Hubbard sand. This type of $\mathrm{Mg}$ response is very common where K-supplying amendments are used (Munson, 1968; Dibb and Thompson, 1985). As with high K fertilizer application rates, we suspect that high alfalfa biomass ash application rates may induce $\mathrm{Mg}$ deficiency under some conditions. Such reductions can potentially limit crop yield and forage quality. Low $\mathrm{Mg}$ in forage crops can cause grass tetany in livestock (Preston and Linser, 1985).

The decline in plant $\mathrm{Zn}$ concentration with increasing ash rate was likely because of increased soil $\mathrm{pH}$. Although we did not detect a change in DTPA-extractable $\mathrm{Zn}$ in soil in the ANOVA, plant $\mathrm{Zn}$ declined by $50 \%$ with a 1 unit rise in $\mathrm{pH}$. Ash application decreased plant Mn only in Hubbard soil and only with the first increment of ash (from 150-95 mg Mn kg${ }^{-1}$ ), consistent with, although greater than, the decline in extractable soil $\mathrm{Mn}$ from 34 to $28 \mathrm{mg} \mathrm{kg}$.

In contrast to $\mathrm{Mg}, \mathrm{Mn}$, and $\mathrm{Zn}$, ash increased $\mathrm{Mo}$ concentration in corn by four-fold at the highest rate of ash application (Table 4). At the highest ash rate, Mo concentration in plants grown in Hubbard, Waukegan, and Wykeham soils was $5.9,2.6$, and $5.5 \mathrm{mg} \mathrm{kg}^{-1}$, respectively. Increased availability of Mo could be because of the direct effect of Mo added by the ash, which 
contained $10 \mathrm{mg} \mathrm{kg}^{-1}$ of soluble (saturated extract) Mo and $26 \mathrm{mg} \mathrm{kg}^{-1}$ total Mo (Mozaffari et al., 2000a). Thus, alfalfa stem biomass ash is within the range of 5.3 to $39.3 \mathrm{mg} \mathrm{kg}{ }^{-1}$ Mo reported in 15 coal fly ashes (Doran and Martens, 1972). Molybdenum response may also have been because of the liming effect of the ash, because solubility and availability of Mo increases with increasing $\mathrm{pH}$ (Adriano, 1980). Under field conditions, plant Mo toxicity has been very rare (Moraghan and Mascagni, 1991). The critical toxicity level for Mo in plants is reported to be 200 to $1000 \mathrm{mg} \mathrm{kg}^{-1}$ tissue DM (Romheld and Marschner, 1991).

Much lower Mo concentrations in forage, however, may induce molybdenosis in livestock, which is a $\mathrm{Cu}$ deficiency-related problem. Some researchers have suggested that Mo concentrations $>5$ to $10 \mathrm{mg} \mathrm{kg}^{-1}$ in plants are hazardous for livestock (James et al., 1968). Others have proposed a $\mathrm{Cu} / \mathrm{Mo}$ ratio of $4: 1$ or greater to insure the $\mathrm{Cu}$ requirement of animals is met (McDowell, 1992), and some researchers have suggested that a $\mathrm{Cu} / \mathrm{Mo}$ ratio lower than 2:1 is likely to cause molybdenosis (Dollahite et al., 1972). At the ash application rate of $2.44 \mathrm{~g} \mathrm{~kg}^{-1}$, the $\mathrm{Cu} / \mathrm{Mo}$ ratio of young corn plants grown in Hubbard, Waukegan, and Wykeham soils was $6.2,7.2$, and 3.9, respectively, and declined to $4.9,3.5$, and 2.4 , respectively, with $4.88 \mathrm{~g} \mathrm{~kg}^{-1}$ ash. We do not know what $\mathrm{Cu} / \mathrm{Mo}$ ratios would occur in corn silage grown under field conditions, but these results raise the possibility that feeding animal with forage crops grown on soils amended with very high ash rates may present a potential nutritional problem if supplemental $\mathrm{Cu}$ is not included in the animal diet.

Concentrations of $\mathrm{B}, \mathrm{Al}$, and $\mathrm{Cu}$ in young corn plants were not affected by ash application (data not shown). Therefore, unlike coal ash where B toxicity has been a major concern (Sims et al., 1995), B toxicity does not appear to be a potential problem for plants grown in soils amended with these rates of alfalfa ash.

\section{Corn Dry Mass}

Corn shoot DM data are presented for each soil separately because the treatment by soil interaction was significant. When all treatments (ash and fertilizer) were included in the analysis of variance, a highly significant treatment effect was observed regardless of soil type. Shoot production was not affected by K fertilizer alone, but increased with P fertilizer in all soils (Table 5). In

Table 5. Effect of alfalfa ash and fertilizer on corn dry mass production after $56 \mathrm{~d}$ in Hubbard, Waukegan, and Wykeham soil.

\begin{tabular}{|c|c|c|c|}
\hline \multirow[b]{2}{*}{ Treatment } & \multicolumn{3}{|c|}{ Soil } \\
\hline & Hubbard & Waukegan & Wykeham \\
\hline \multirow[b]{2}{*}{ None } & & - g plant ${ }^{-1}$ & \\
\hline & 7.1 & 4.9 & 0.6 \\
\hline$K$ fertilizer & 7.2 & 3.8 & 0.7 \\
\hline P fertilizer & 8.6 & 7.3 & 2.3 \\
\hline $\mathbf{K}+\mathbf{P}$ fertilizer & 9.2 & 7.1 & 2.2 \\
\hline $4.88 \mathrm{~g} \mathrm{~kg}^{-1}$ ash $+K$ fertilizer & $\mathbf{7 . 8}$ & 5.2 & 1.2 \\
\hline $4.88 \mathrm{~g} \mathrm{~kg}^{-1}$ ash $+P$ fertilizer & 10 & 7.4 & 1.7 \\
\hline $4.88 \mathrm{~g} \mathrm{~kg}^{-1}$ ash & 8.0 & 5.6 & 0.9 \\
\hline MSD $\dagger$ & 1.2 & 0.9 & 0.5 \\
\hline
\end{tabular}

$\dagger$ MSD Minimum significant difference according to Waller-Duncan test at $P=0.05$. all soils, shoot mass in the ash $+\mathrm{K}$ treatment did not differ from the ash-only treatment at the same rate. The only case where ash application rate appeared to increase shoot DM was in Wykeham soil (Fig. 3), but most of that response appeared to be because of some ash-mediated effect other than to K supplied by ash. These data suggest that in this container study, shoot $\mathrm{DM}$ was not enhanced by $\mathrm{K}$ addition, regardless of the K source.

Corn DM response to ash was dependent on soil type (Fig. 3, Table 3). Low rates of ash increased and high rates of ash decreased DM in Hubbard soil. In contrast, DM increased linearly with ash in Wykeham soil, but was not affected in Waukegan soil. Lower yield of plants grown in Hubbard soil at the two highest rates of ash may be because of reduced $\mathrm{Ca}$ and $\mathrm{Mg}$ uptake associated with high K supply. At harvest, the corn plants grown in Hubbard soil were $\sim 30 \mathrm{~cm}$ tall. The critical $\mathrm{Mg}$ or $\mathrm{Ca}$ concentration for field-grown corn at that height in Minnesota is $3 \mathrm{~g} \mathrm{~kg}^{-1}$ (Overdahl, 1987), whereas at the highest rate of ash application, concentrations of $\mathrm{Ca}$ and $\mathrm{Mg}$ in corn plants grown in Hubbard soil were 2.4 and $2.1 \mathrm{~g} \mathrm{~kg}^{-1}$, respectively. Etiegni et al. (1991b) reported that bean yield started to decline when $\mathrm{K}$ supply by wood ash was more than $460 \mathrm{~kg} \mathrm{ha}^{-1}$. In contrast to the Hubbard soil, Ca concentration of plants grown in Waukegan and Wykeham soils at the highest ash rate was 4.0 and $9.6 \mathrm{~g} \mathrm{~kg}^{-1}$, respectively, and concentrations of $\mathrm{Mg}$ were 2.7 and $4.3 \mathrm{~g} \mathrm{~kg}^{-1}$, respectively.

In Hubbard soil, salinity could be another factor contributing to yield reduction at high ash rates. The amount of moisture retained by the sand-textured soil at field capacity was very low (Table 1); therefore, the actual concentration of soluble salts in this soil was considerably higher than in either Waukegan or Wykeham soil, a condition not reflected in 1:1 soil/water extraction. It is also possible that an interaction between high $\mathrm{P}$ availability and low $\mathrm{Zn}$ contributed to decreased DM at high ash rates in the Hubbard soil. Further research is needed to determine the cause of this yield decline at high ash rates.

\section{CONCLUSION}

This growth chamber study indicated that alfalfa stem gasification ash is a potentially useful source of $\mathrm{K}$ and possibly $\mathrm{P}$, and is an effective liming agent in acid soils. At ash application rates exceeding $7.5 \mathrm{~g} \mathrm{~kg}^{-1}$, plant growth declined to less than one-half the maximum on the sand-textured soil, but no yield depression occurred on finer-textured soils. At very high rates of ash excessive availability and uptake of Mo may become a forage quality concern. We conclude that this ash is not likely to pose significant risk of excessive inorganic element and metal accumulation in either soil or plants, when used at rates based on crop yield goal and soil test value. The nutrients in the alfalfa stem gasification ash can potentially be safely recycled in the agroecosystem, providing added value to this method of renewable electrical energy production. 


\section{ACKNOWLEDGMENT}

This work was supported in part with funds approved by the Minnesota Legislature, ML 1997, Chapter 216, Sec. 15, Subd. 12 (c) as recommended by Legislative Commission on Minnesota Resources from the Minnesota Future Resources Fund and by funds from Minnesota Valley Alfalfa Producers, through a grant provided by United States Department of Energy.

\section{REFERENCES}

Adriano, D.C., A.L. Page, A.A. Elseewi, A.C. Chang, and I. Straughan. 1980. Utilization and disposal of fly ash and other coal residues in terrestrial ecosystems: A review. J. Environ. Qual. 9: 333-344

Barrow, N.J., and R.E. Mendoza. 1990. Equations for describing sigmoid yield response and their application to some physiological response by lupins and subterranean clover. Fert. Res. 22:181-188.

Carman, H.J. (ed.) 1934. Essays upon field husbandry in New England and other papers 1748-1762 by Jared Eliot. Columbia University Press, New York.

Clapham, W.M., and L.M. Zibilske. 1992. Wood ash as a liming agent. Commun. Soil Sci. Plant Anal. 23:1209-1227.

Codling, E.E., and R.J. Wright. 1998. Plant uptake of selenium, arsenic, and molybdenum from soil treated with coal combustion byproducts. Fresenius Environ. Bull. 7:118-125.

Combs, S.M., and M.V. Nathan. 1998. Soil Organic Matter. p. 53 In Recommended chemical soil test procedures for the North Central Region. North Central Reg. Res. Publ. No. 221 (Revised). Jan. 1998. Missouri Agri. Exp. Stn. SB1001. Columbia, MO.

Combs, S.M., and D.A. Whitney. 1998. p. 59 In Recommended chemical soil test procedures for the North Central Region. North Central Reg. Res. Publ. No. 221 (Revised). Jan. 1998. Missouri Agri. Exp. Stn. SB1001. Columbia, MO

Dahlquist, R.L., and J.W. Knoll. 1978. Inductively coupled plasmaatomic emission spectrometry: Analysis of biological materials and soils for major, trace, and ultra-trace elements. Appl. Spectrosc. 32:1-30.

Dibb, D.W., and W.R. Thompson, Jr. 1985. Interaction of potassium with other nutrients. p. 515-534. In R.D. Munson (ed.) Potassium in agriculture. ASA, CSSA, and SSSA, Madison, WI.

Dollahite, J.W., L.M. Cook, D. Hightower, E.M. Bailey, and J.R. Kyzar. 1972. Copper deficiency and molybdenosis intoxication associated with grazing near a uranium mine. Southwestern Vet. 9:47.

Doran, J.W., and D.C. Martens. 1972. Molybdenum availability as influenced by application of fly ash to soil. J. Environ. Qual. 1: $186-189$.

Eliot, J. 1934. The second essay. p. 27-52. In H.J. Carman (ed.) Essays upon field husbandry in New England. Columbia University Press, New York.

Elseewi, A., I.R. Straughan, and A.L. Page. 1980. Sequential cropping of fly ash-amended soils: Effects on soil chemical properties and yield and elemental composition of plants. Sci. Total Environ. 15:247-259.

Erich, M. 1991. Agronomic effectiveness of wood ash as a source of phosphorus and potassium. J. Environ. Qual. 20:576-581.

Erich, M., and T. Ohno. 1992. Trimetric determination of calcium carbonate equivalence of wood ash. Analyst (Cambridge) 117:993995.

Etiegni, L., A.G. Campbell, and R.L. Mahler. 1991a. Evaluation of wood ash disposal on agricultural land. I. Potential as a soil additive and liming agent. Commun. Soil Sci. Plant Anal. 22:243-256.

Etiegni, L., A.G. Campbell, R.L. Mahler, and B. Shafii. 1991b. Evaluation of wood ash disposal on agricultural land. II. Potential toxic effects on plant growth. Commun. Soil Sci. Plant Anal. 22:257-267.

Francis, C.W., E.C. Davis, and J.G. Goyert. 1985. Plant uptake of trace elements from coal gasification ashes. J. Environ. Qual. 14:561-569.

Hammermeister, A.M., M.A. Naeth, and D.S. Chanasyk. 1998. Implications of fly ash application to soil for plant growth and feed quality. Environ. Technol. 19:143-152.

Huang, H., A.G. Campbell, R. Folk, and R.L. Mahler. 1992. Wood ash as a soil additive and liming agent for wheat: Field studies. Commun. Soil Sci. Plant Anal. 23:25-33.

James, D.W., T.L. Jackson, and M.E. Harward. 1968. Effect of molyb- denum and lime on the growth and molybdenum content of alfalfa plants grown in acid soils. Soil Sci. 105:397-402.

Johnson, F.J. 1990a. Agricultural liming materials. 955.01. In K. Helrich (ed.) Official methods of analysis of the Association of Official Analytical Chemists (AOAC), 15th ed. AOAC, Arlington, VA.

Johnson, F.J. 1990b. Fertilizers. 960.02, 963.03, 978.01. In K. Helrich (ed.) Official methods of analysis of the Association of Official Analytical Chemists (AOAC), 15th ed. AOAC, Arlington, VA.

Krejsl, J.A., and T.M. Scanlon. 1996. Evaluation of beneficial use of wood fired boiler ash on oat and bean growth. J. Environ. Qual. 25:950-954.

Kuo, S. 1996. Phosphorus. p. 869-920. In D.L. Sparks (ed.) Methods of soil analysis. Part 3. SSSA Book Ser. 5. SSSA, Madison, WI.

Matsi, T., and V.Z. Keramidas. 1999. Fly ash application on two acid soils and its effect on salinity, $\mathrm{pH}, \mathrm{B}, \mathrm{P}$ and on rye grass growth and composition. Environ. Pollut. 104:107-112.

McDowell, L.R. 1992. Minerals in animal and human nutrition. Academic Press, Toronto.

Meyers, N.L., and M.J. Kopecky. 1998. Industrial wood ash as a soil amendment for crop production. Tappi J. 81:123-130.

Miller, R.O. 1998. Microwave digestion and dissolution in a closed vessel. p. 69-75. In Y.P. Karla (ed.) Handbook of reference methods for plant analysis. CRC Press, New York.

Mitchell, C.C., and E.D. Black. 1997. Land application of boiler wood ash in the Southeastern United States. p. 204-225. In J.E. Rechcigl and H.C. MacKinnon (ed.) Agricultural uses of by-products and wastes. 1st ed., Vol. 1. American Chemical Society, Washington, DC.

Moliner, A.M., and J.J. Street. 1982. Effect of fly ash and lime on growth and composition of corn (Zea mays L.) on acid sandy soils. Soil Crop Sci. Soc. Florida Proc. 41:217-220.

Moraghan, J.T., and J.R. Mascagni. 1991. Environmental and soil factors affecting micronutrient deficiencies and toxicities. p. 371426. In J.J. Mortvedt et al. (ed.) Micronutrients in agriculture. 2nd ed. SSSA Book Ser. 4. SSSA, Madison, WI.

Mozaffari, M., C.J. Rosen, M.P. Russelle, and E.A. Nater. 2000a. Chemical characterization of ash from gasification of alfalfa stem: Implications for ash management. J. Environ. Qual. 29:963-972.

Mozaffari, M., C.J. Rosen, M.P. Russelle, and E.A. Nater. 2000b. Corn and soil response to application of ash generated from gasified alfalfa stems. Soil Sci. 165:896-907.

Munson, R.D. 1968. Interaction of potassium and other ions. p. 321354. In V.J. Kilmer et al. (ed.) The role of potassium in agriculture. ASA, CSSA, and SSSA, Madison, WI.

Muse, J.K., and C.C. Mitchell. 1995. Paper mill boiler ash and lime by-product as soil liming materials. Agron. J. 87:432-438.

Naylor, L.M., and E.J. Schmidt. 1986. Agricultural use of wood ash as a fertilizer and liming material. Tappi J. 69:114-119.

Naylor, L.M., and E.J. Schmidt. 1989. Paper mill wood ash as a fertilizer and liming material: Field trials. Tappi J. 72:199-206.

Ohno, T., and M.S. Erich. 1990. Effect of wood ash application on soil $\mathrm{pH}$ and soil test nutrient levels. Agric. Ecosyst. Environ. 32: 223-239.

Overdahl, C.J. 1987. Plant analysis: Sampling and interpretation. AGFS-3176. Minnesota Agricultural Experiment Station, University of Minnesota, St. Paul, MN.

Preston, R.L., and J.R. Linser. 1985. Potassium in animal nutrition. p. 595-619. In R.D. Munson (ed.) Potassium in agriculture. ASA, CSSA, and SSSA, Madison, WI.

Randall, G.W., T.K. Iragavarapu, and S.D. Evans. 1997. Long-term $\mathrm{P}$ and $\mathrm{K}$ applications: Effect on soil test incline and decline rates and critical soil test levels. J. Prod. Agric. 10:565-571.

Reed, S.T., and D.C. Martens. 1996. Copper and zinc. p. 703-722. In D.L. Sparks (ed.) Methods of soil analysis. Part 3. SSSA Book Ser. 5. SSSA, Madison, WI.

Rehm, G., M. Schmitt, and R. Munter. 1995. Fertilizer recommendations for agronomic crops in Minnesota. BU-6240-E. Minnesota Agricultural Experiment Station, University of Minnesota, St Paul, MN

Romheld, V., and H. Marschner. 1991. Function of micronutrients in plants. p. 297-328. In J.J. Mortvedt et al. (ed.) Micronutrients in agriculture. 2nd ed. SSSA Book Ser. 4. SSSA, Madison, WI.

Sale, Y.L., M.A. Naeth, and D.S. Chanasyk. 1996. Growth response of barley on unweathered fly ash amended soil. J. Environ. Qual. 25:684-691. 
SAS. 1996. SAS users' guide: Statistics. version 5 ed. SAS Inst. Cary, NC.

Sims, J.T., B.L. Vasilas, and M. Ghodrati. 1995. Evaluation of fly ash as a soil amendment for the Atlantic Coastal Plain. II. Soil chemical properties and crop growth. J. Water Soil Air Pollut. 81:363-372.

Sumner, M.E., and W.P. Miller. 1996. Cation exchange capacity and exchange coefficients. p. 1201-1229. In D.L. Sparks (ed.) Methods of soil analysis. Part 3. SSSA Book Ser. 5. SSSA, Madison, WI.

Vance, E.D. 1996. Land application of wood-fired and combination boiler ashes: An overview. J. Environ. Quality. 25:937-944.

Voundinkana, J.C., A. Demeyer, and M.G. Verlo. 1998. Availability of nutrients in wood ash amended tropical acid soils. Environ. Technol. 19:1213-1221.
Watson, M.E., and J.R. Brown. 1998. pH and lime requirement. p. 13. In Recommended chemical soil test procedures for the North Central Region. North Central Reg. Res. Publ. No. 221 (Revised). Jan. 1998. Missouri Agri. Exp. Stn. SB 1001. Columbia, MO.

Whitney, D.A. 1998. Soil salinity. p. 59. In Recommended chemical soil test procedures for the North Central Region. North Central Reg. Res. Publ. No. 221 (Revised). Jan. 1998. Missouri Agri. Exp. Stn. SB 1001. Columbia. MO.

Wilbur, D., S. Shurts, and C.V. Hanson. 1998. Minnesota Agri Power: The power of alfalfa. Bio energy 98. p. 21-28. Expanding bioenergy partnerships. Proc. Volume 1. Madison, WI. 4-8 Oct. 1998. Great Lakes Regional Bioenergy Program, Madison, WI.

\title{
Subsurface Drip Irrigation and Fertigation of Broccoli: II. Agronomic, Economic, and Environmental Outcomes
}

\author{
Thomas L. Thompson*, Thomas A. Doerge, and Ronald E. Godin
}

\begin{abstract}
Subsurface drip irrigation offers potential for increased water and $\mathbf{N}$ fertilizer use efficiency, and decreased groundwater $\mathrm{NO}_{3}$ pollution. Replicated factorial experiments consisting of four rates of $\mathbf{N}$ fertilizer application (60-500 $\left.\mathrm{kg} \mathrm{ha}^{-1}\right)$ and three target soil water tensions (SWT) (low, medium, and high) were conducted on subsurface dripirrigated broccoli (Brassica olearacea L. Italica) during three winter growing seasons in southern Arizona. Objectives were to (i) determine effects and interactions of irrigation water and $\mathrm{N}$ inputs on net economic return, residual soil $\mathrm{NO}_{3}-\mathrm{N}$, and unaccounted fertilizer $\mathrm{N}$, and (ii) use abstract spatial analysis techniques to simultaneously evaluate agronomic, economic, and environmental production functions during three growing seasons. Spatial analysis was used to identify overlap of acceptable zones of marketable yield, net return, and unaccounted fertilizer $\mathbf{N}$. Acceptable yields and net return were defined as $\geq 95 \%$ of maximum predicted response within the range of the treatments, and acceptable unaccounted fertilizer $N$ was defined as $\leq 40 \mathrm{~kg} \mathrm{ha}^{-1}$. During this study, $>95 \%$ of maximum net return encompassed $\mathbf{N}$ rates of 300 to $500 \mathrm{~kg} \mathrm{ha}^{-1}$, and SWTs of 7 to $25 \mathrm{kPa}$. There was little accumulation of $\mathrm{NO}_{3}$ in the top $0.9 \mathrm{~m}$ of soil when $\leq 350 \mathrm{~kg} \mathrm{~N} \mathrm{ha}^{-1}$ were applied. Unaccounted $\mathbf{N}$ increased with excessive $\mathbf{N}$ and water inputs, and accounted for as much as $46 \%$ of $\mathrm{N}$ applied. Overlap of acceptable zones of agronomic, economic, and environmental production criteria was achieved in each year. Areas of overlap were bounded by 300 to $325 \mathrm{~kg} \mathrm{~N} \mathrm{ha}^{-1}$ and 8.5 to $12 \mathrm{kPa}$ in 1993-1994, 350 to 500 $\mathrm{kg} \mathrm{N} \mathrm{ha}^{-1}$ and 11 to $14 \mathrm{kPa}$ in 1994-1995, and 340 to $410 \mathrm{~kg} \mathrm{~N} \mathrm{ha}^{-1}$ and 11 to $24 \mathrm{kPa}$ in 1995-1996.
\end{abstract}

$\mathrm{C}$ ONCERN ABOUT the impacts of agricultural practices on the environment is increasing. These concerns include the leaching of nitrate from crop production areas into aquifers. Nitrate contamination of aquifers is especially pronounced in the irrigated Southwest. The percentage of wells testing above the federal drinking

T.L. Thompson, Dep. of Soil, Water, and Environmental Science, University of Arizona, 429 Shantz Bldg. \#38, Tucson, AZ 85721; T.A. Doerge, Pioneer Hi-Bred International, Inc., P.O. Box 1150, Johnston, IA 50131; R.E. Godin, Colorado State University, Rogers Mesa Research Center, 3060 Highway 92, Hotchkiss, CO 81419. Received 2 Nov. 1999. *Corresponding author (thompson@ag.arizona.edu).

Published in Soil Sci. Soc. Am. J. 66:178-185 (2002). water standard of $10 \mathrm{mg} \mathrm{NO}_{3}-\mathrm{N} \mathrm{L}^{-1}$ in Arizona, California, and Texas ranges from 9.4 to $13.9 \%$. In contrast, an average of $6.4 \%$ of all wells sampled in the USA were above $10 \mathrm{mg} \mathrm{L}^{-1}$ (Fedkiw, 1991).

The use of subsurface drip irrigation is a practice that offers the potential for increased water and $\mathrm{N}$ fertilizer use efficiency, and decreased groundwater $\mathrm{NO}_{3}$ pollution (Phene, 1999). The use of subsurface drip irrigation is increasing in the desert Southwest and California. Currently, 3600 ha in Arizona and 22300 ha in California are irrigated in this manner (Anonymous, 1994; 1998). Several recent studies have illustrated the efficient nature of subsurface drip irrigation for delivery of water and nutrients (Pier and Doerge, 1995b; Thompson and Doerge, 1996b).

Water and $\mathrm{N}$ are the two inputs to irrigated cropping systems having the most impact on agronomic, economic, and environmental outcomes (Letey et al., 1977). These three criteria have only recently been evaluated simultaneously for drip-irrigated crops. The interactive effects of water and $\mathrm{N}$ management on yields have been reported for several drip-irrigated vegetable crops (Phene and Beale, 1976; Bar-Yosef and Sagiv, 1982a, 1982b; Feigin et al., 1982; Yanuka et al., 1982; Pier and Doerge, 1995b; Thompson and Doerge, 1996a). Recently, Pier and Doerge (1995a), Thompson and Doerge (1996b), and Thompson et al. (2000) have evaluated agronomic, economic, and environmental outcomes for several subsurface drip-irrigated crops. Similar methods were used in this study to simultaneously evaluate marketable yield, net economic return, and unaccounted fertilizer $\mathrm{N}$ for subsurface drip-irrigated broccoli.

The objectives of this study were to (i) determine effects and interactions of irrigation water and $\mathrm{N}$ inputs on net economic return, residual soil $\mathrm{NO}_{3}-\mathrm{N}$, and unaccounted fertilizer $\mathrm{N}$, and (ii) use abstract spatial analysis techniques to evaluate agronomic, economic, and environmental production functions during three growing seasons.

Abbreviation: SWT, soil water tension. 